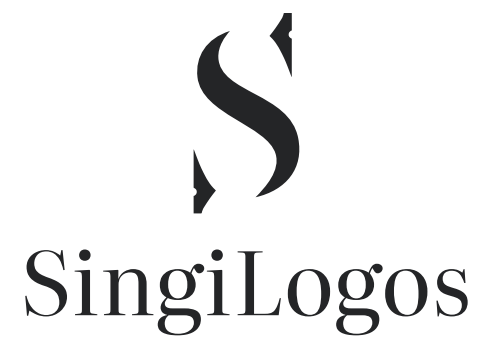

SINGILOGOS 2021, 1(1): 29 - 41

ISSN: $2812-7005$

UDK: 141.131 Прокло Дијадох

27-185 Немесије

27-185:121"04"

DOI: 10.18485/us_singilogos.2021.1.1.4

Original paper/Originalni naučni rad

\title{
THE METAPHYSICAL AND ESCHATOLOGICAL CONTEXTS OF ANTHROPOLOGY: TOWARDS A MEETING OF NEOPLATONISM [PROCLUS (412)] WITH CHRISTIANITY [NEMESIUS EMESIS (400)]
}

\author{
Apostolos A. Kaproulias* \\ Professor (SEP) Hellenic Open University, \\ Patras-Greece
}

\begin{abstract}
:
In the present work we are concerned with whether and to what extent it is possible for a human conscience to introduce for itself self-regulation of "freedom" or even exceeding its metaphysical determinations. For Nemesius Emesis, a human consciousness communicates its presence in the existent - as an individual or as a collective expression - according to the way in which it communicates the divine communion. This is clearly a direct reference to the realm of the divine Consciousness and not through the collective unconscious (universal Soul) as in the neo-Platonic philosopher Proclus. Despite their above-mentioned differentiation, the two thinkers will agree that any relationship that is ultimately formed, even in the field of the wider paths of a human consciousness, needs to take place in the field of divine expediency and not in that of the cosmological surfaces.
\end{abstract}

\section{Article info:}

Received: April 8, 2021

Correction: May 14, 2021

Accepted: July 5, 2021

\section{Keywords:}

Proclus,

Nemesius Emesis,

Anthropology,

human consciousness,

soul,

matter.

\section{INTRODUCTION}

In this study, we will undertake the task of demonstrating whether it is possible for the human consciousness - both to the neo-Platonist philosopher Proclus (412) and to the Christian thinker Nemesius Emesis (400) - to regulate its mental or psychological state independently or not. from its metaphysical standards or origins. That is, if she is on her own able to self-regulate her existential state and to what extent. This target-research parameter, however, is rather part of specialized perspectives, which are opened in the area of Ontology. However, according to C. Hann, Anthropology is inextricably linked with Ontology. After all, both of the above philosophical and even theological branches utilize, in their theoretical discoveries, common concepts, such as, for example, 
those of "identity", "self", "person" and "world"1. Therefore, it is indeed of particular research interest to detect, to the extent to which it is possible, whether in the Neoplatonic and Byzantine philosophical traditions the human consciousness, as the "indefi-

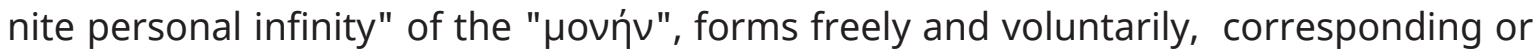
disproportionate and with other ontological or, more specifically, self-conscious states during the "specific and defined infinity" of its presence 2.

\section{A. THE "HOW" OF THE FORMATION OF HUMAN REASON}

The underlying principle, which permeates the ontological system of the Neoplatonic philosopher, is that the existing has - either in its universal expression or in its unfolding through its individual manifestations - divine and metaphysical specifications. However, in order to avoid any reasoning connotations that would allow the above labeling to be perceived as introducing an extended homogenetics and, mechanistic type, causality, Proclus hastens to present the appropriate explanations. Remaining, in fact, at this point as well, a consistent admirer of Platonic philosophy, the late headmaster of the Academy will note that any divisions of the existing appear, are determined - inherently and essentially - not so much by their relatives but mainly by their particular apoptoticmetaphysical origins. Therefore, in the realm of perceptible reality, each category of subject has inherent and special possibilities, arising accordingly and "subtly" appearing from their initial existential state, that is, that which had been pre-empirically granted to them ${ }^{3}$.

But also in the internal environment of each ontological order or series, individual existential structures are formed as species, on which, remarkably, hierarchies of this kind emerge, proportional - first and foremost - from the quality of their involvement in the processes of the world. Proclaiming, and at this point, Proclus his relevant argument from what is relevant in the Platonic dialogue Phaedrus, he will argue that in the region of $E i \delta \tilde{\omega} v$ - as, for example, that of the human soul - it is possible to identify extremes between them differences. In fact, in the case of a rational interiority, this situation or reality is entirely characteristic of its moral and behavioral choices, so - for the most part - it will permanently confirm both its "vertical" self-references and its "horizontal" deviations from its other similar entities ${ }^{4}$.

In the case, however, that we are interested in, that is, in that of rational mental states or human consciences, such an interpretive view does not exclude the existence of "intermediate" beings within the said genus.

1 Hann 2014, 189.

2 Goeschel-Vickroy 1877, 192.

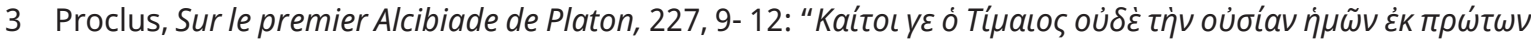

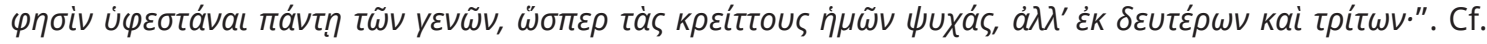
Platon, Timaeus, $41 \mathrm{~d} 7$.

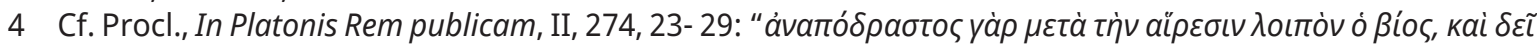

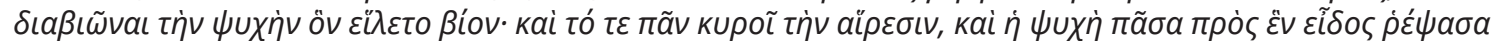

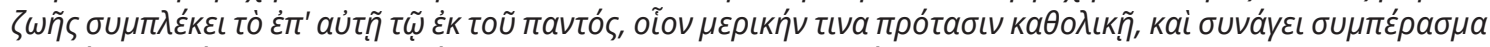

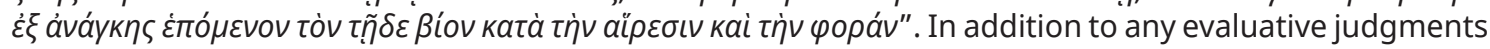
that will be made, the verses highlight the internal implications of anthropological situations. 
We would point out that here, too, we are talking about human beings of this nature, who have not yet secured for themselves an adequate or "simple" ontological selfmeaning. That is why they maintain their existential integrity in a "mixed" -one of the immediately extreme mainly consciences- form. Even if, however, such a view does not emerge directly from the relevant verse of Phaedrus, which Proclus mentions, we would argue that it is the pre-eminently theoretical basis of both the moral and the anthropological broader positions of the neoplatonic philosopher ${ }^{5}$.

Under the above, interpretive case of reading, we would further note that a human soul, in its ontological formations and its productive projections, will be a personalized psychic reality which, consequently, will have its own mental possibilities. In other words, it will have succeeded in establishing a certain communicative relation - as persistent and

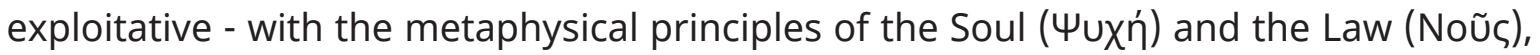
while, at the same time, it will maintain -through them- as its potential performer and its relation to the productive manifestations. of the original One ('Evád $\delta \varsigma)^{6}$. Beyond that, however, we should not lose sight of the fact that for Proclus each human consciousness will have its autonomous expression under its own terms, which will now reflect in a new entity, with absolute ontological precision, the above communication status or condition.

In this sense, each individual consciousness will emerge from the original, having previously assumed from the whole of the Body - the ultimate reality in the hierarchy the ontological before the creation of the physical world - a certain perceptible form. What, therefore, will constitute - on a first structural foundation- the noticeable difference between the respective human consciences will be the existential, so to speak, degree of attainment of the functional array of a soul, a mind and an individual body, respectively the ontological specifications of each of them will be applied precisely. In terms of, in fact, intra-cosmic eschatology - we will insist on the following thematic relevance - we would point out that it belongs exclusively to the human consciousness in which, in its worldly presence, a hierarchical order between its three dimensions (mind, body, soul) will choose to notify its presence in the existing. It is understandable that, from a teleological point of view, the priority of the mind is imposed over the soul, as well as that, after all, over the body?.

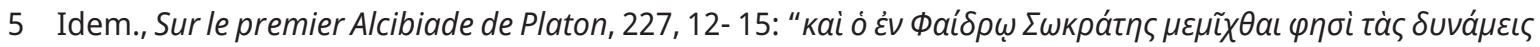

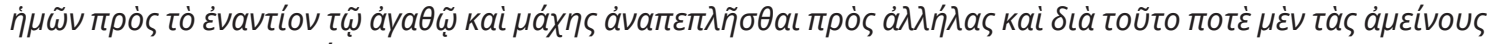

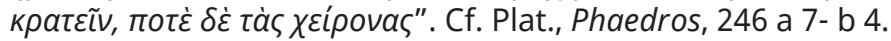

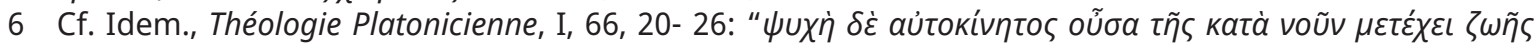

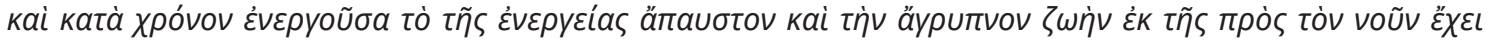

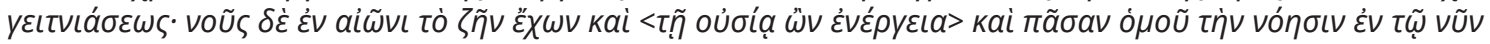

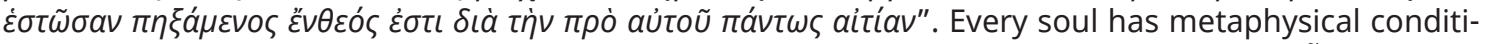

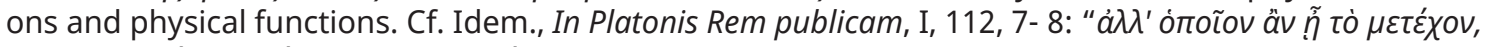

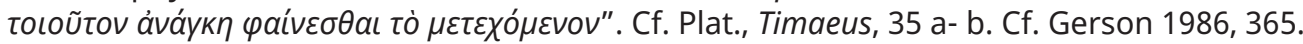

7 Cf. Procl., Théologie Platonicienne, III, 21, 25- 27: "Kai yà

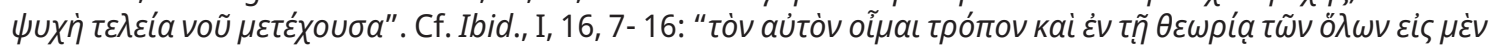

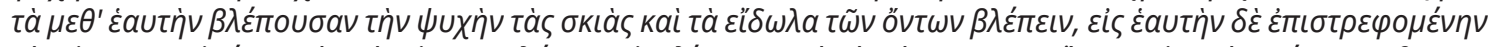

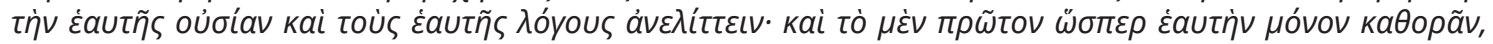

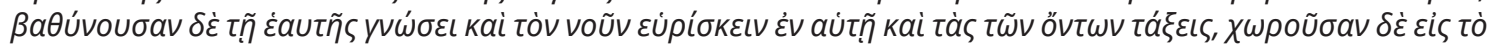

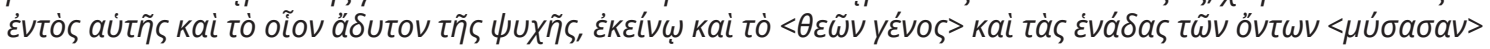
$\theta \varepsilon a ́ \sigma a \sigma \theta a \iota^{\prime \prime}$. 
According to the above, the individualized presence of human consciousness is determined, first, by the subjective and highly personal way in which it chooses to participate in all of its metaphysical origins. On the other hand, we should not overlook the fact that the existential state of a human being is clearly determined also on the basis of the way in which it formally defines its otherwise innate relation to other entities of the same order or order ${ }^{8}$. Thus, we would conclude that each individual consciousness has, by its nature, the possibility of developing an ontological or existential type of dual energy, both as a participant of its ontological predecessors, and as a participant by the following entities ${ }^{9}$.

In both cases, however, of the above communication conditions, in which a human consciousness participates, we must, from an epistemological point of view, have in mind a highly decisive point, which Proclus does not fail to introduce in the field of his relevant reasoning. Any difference between the rational consciences, then, is by no means removed, even in the field of their "intra-class" intercourse. Thus, a human consciousness, either as a participant or as a participant entity, is not activated in order to "shock" the generality of the particularity of any subjective element that takes place in communication. On the contrary, it is called to perceive its difference from the rest as that motivating perspective, through which it will contribute - depending of course on its quality standards - to the need to strengthen and positive-evaluative promotion of all its like-minded beings ${ }^{10}$.

Admittedly, there is no ontological system similar to that of Proclus in the Nemesius of Emesis. And, of course, in the field of human consciousness, the Christian thinker does not refer to spiral - horizontal and vertical - developments, amenable to moral and anthropological documentation. Despite any differences between them, the two thinkers seem to converge on the view that each human being has metaphysically secured for himself a field of existential legacy capable of differentiating and communicating it to others. In Proclus, this store principle is directly related to who in the (internal) relationship of an individual soul, an individual law and the corresponding body. For Nemesius, however, the above perspective first of all depends on the degree of the overlapping tolerant relationship, which a human being has developed both with the living space of the horses and with the spiritual environment of the rational beings ${ }^{11}$. Therefore, according to the Christian thinker, each human consciousness will substantiate its presence in a special way, highly indicative, we would note, of the personal appropriation of the

8 Cf. Idem., The Elements of Theology, 88, 28- 34. Cf. Sheppard 1982, 220.

9 Procl., In Platonis Rem publicam, I, 134, 22- 26: “ì yà $\rho$ ó

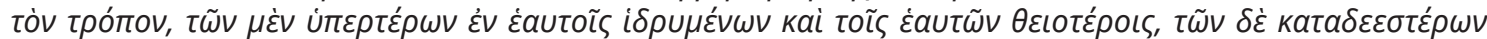

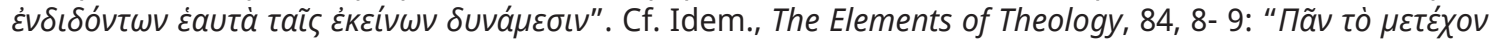

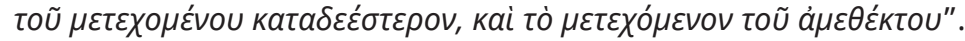

10 Of course, any form of communication that comes to the fore does not violate the original boundaries,

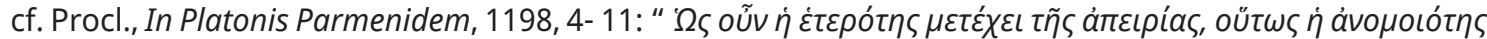

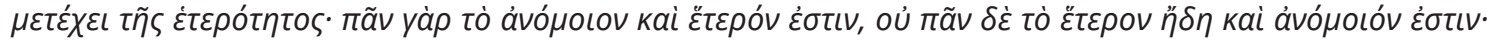

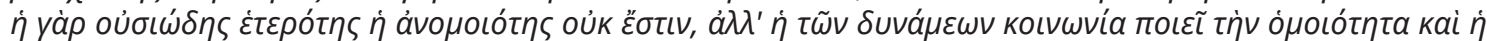

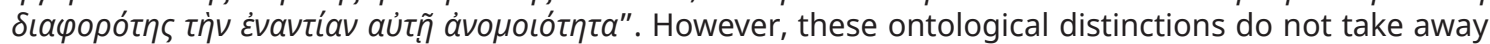
society. Cf. Ibid., 668, 7-15.

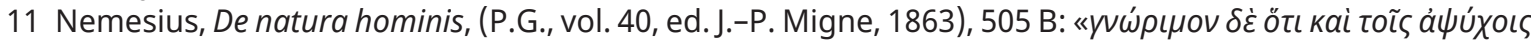

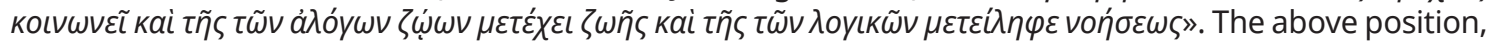
however, is not absent from Proclus in the way he presents it in his work Sur le premier Alcibiade de Platon. 
horse and the rational element of the existing, by analogous of course analogy. As such, then, ontological conditions will act and will "welcome" the effect of the innate beings ${ }^{12}$, a detail which is inscribed in anthropological materialism.

In addition, we have to mention that the Bishop of Emesis does not follow Proclus directly in his reasoning regarding the metaphysical categories of beings, with the genera, as well as with the species and, mainly, with those of the individual rational beings. However, the Christian thinker, when referring to a rational entity, does not seem to move away from Proclus' ontological model, at least as far as its peaks are concerned. Under this interpretive version, then, we would first note that, according to Nemesius, any human consciousness will define its existential state during the initiatives that it will choose, as autonomous, to develop ${ }^{13}$. Thus, any human consciousness will not only be defined as belonging to one, special ontological or, more correctly, bodily joints, class of gender, but it will also be perceived as a special being, qualitatively different from the rest of its like-minded or similar. The above, however, dual manifestation of the state and rational consciences is subject, according to the Christian thinker, to the permanent -eschatological type- intervention of the divine providence, which constantly ensures both the coherence and the continuity of the human race, as well as for the evaluative presence and inter-communication of the individual rational beings ${ }^{14}$.

From what has been said before, therefore, we would first argue that, although some modern scholars - such as A. Charles - argue that the traditional interpretation of human consciousness "requires" self- and its hetero-definition in terms that touching on a "material analogy", such an interpretation is deeply judged to be rather inadequate ${ }^{15}$. In Proclus, but also in Bishop Emesis, such a view derives its force in a pre-theoretical or even preparatory reading context, aspects or aspects of which we have already, more or less, highlighted. However, in an advanced field of reasoning, we would note that the human conscience is understood primarily as the immediately "realized self", that is, as a subjective and, at the same time, universal reality, which gradually or evolutionarily shapes, in the context here, the its moral self-regulation ${ }^{16}$. After all, both thinkers seem to be dominated by the belief that, already from its initial-genetic projections, every human consciousness has the same - as a being - to secure for itself its existential-personal independence, as well as the similarity - that is, the communication from the beginning and elementally formed - after the other like-minded entities ${ }^{17}$.

Our assessment, then, is that Proclus and Nemesius Emesis rather agree on the terms of the formation of human consciousness but, of course, also on those which formally give it certain possibilities for the development of an eschatological proposition of intersubjectivity. Nevertheless, we would argue that we should not lose sight of such a decisive difference between the two thinkers. In Nemesius, a human consciousness is "educated" in its individual and collective actions according to the way in which it understands

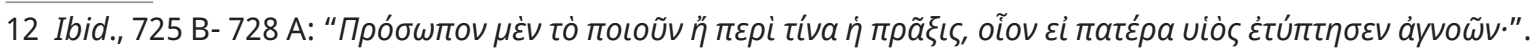

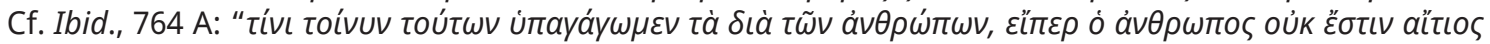

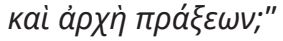

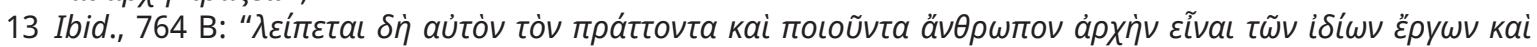

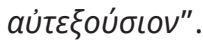

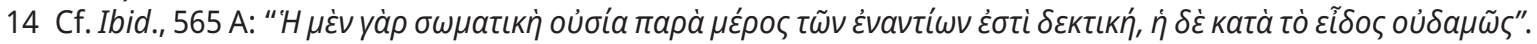

15 Charles 1971, 243.

16 Cf. Whiton-Calkins 1908, 280.

17 Cf. Bastid 1969, 369. Cf. Terezis 1991, 309. 
for itself the foresighted worldly projections of God, that is, of absolute spiritual terms, of universal Consciousness. In Proclus, however, such a process strictly requires the mediation - between the divine and the human consciousness - of the collective consciousness (Soul). For H. E. Barnes, in fact, it was an entity which, remarkably, in the Neoplatonic circle should by no means be regarded as a form of individual consciousness, because then, rather, we would be referring to a kind of "supernatural person"18. However, this assessment of $\mathrm{H}$. E. Barnes breaks, in a way, the wider relations of analogy that pervade the ontological system of Proclus in particular and ${ }^{19}$, to a certain extent, we would note that it does indeed introduce interpretive difficulties. However, it would be possible to accept the above view of the scholar, in spite of the relevant clarifications, which J. Trouillard also expresses in this regard. In particular, this scholar argues that the collective consciousness, according to the Neoplatonic scholar, does not remain as such in a solid existential state, but is "transformed" into a universal Consciousness, from the moment it undertakes to communicate to the existent what transcends it, in fact, by a certain "constituent and constituted" act ${ }^{20}$.

Concluding our relevant reasoning, we would argue that in both the Neoplatonic scholar and the Christian thinker a human consciousness is in fact the "focus" of a series of intersubjective ontological compositions, reconstructing but also decomposing for its teleological completeness only in the event that such processes overlap a broader salvific perspective. And, as long as the individual consciousness maintains its existential independence through its permanent reference to the spiritual field of universal Consciousness or to both Theoretical and Practical Reason, so much will it draw, especially reflexively, to its region and to any human being. maintained by an intrinsic relationship or contact ${ }^{21}$.

\section{B. THE "FOR WHAT" OF THE EXISTENCE AND PRESENCE OF HUMAN CONSCIOUSNESS}

Following what we have pointed out earlier and starting our reasoning here from Proclus, we recall that, according to the Neoplatonic scholar, any behavioral choices of a human being depend entirely on or intertwined with the way in which it is appropriately appropriated and appropriated, divine standards, reasonableness it has. Therefore, this - grounded - possibility of "consciousness" is permanently activated under such a purposeful arrangement, so that psychology formally introduces its terms on the human interior. In this sense, therefore, the vontıkóv part of the soul - during its internal processes - will

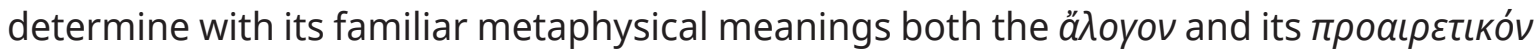
element, in order to ensure a reasonably arising, mental and internal of the individual harmony ${ }^{22}$.

18 Barnes 1945, 566.

19 Charles 1971, 245.

20 Trouillard 1971, 448. Cf. Trouillard 1982, 185-186.

21 Cf. Clément 1973, 129.

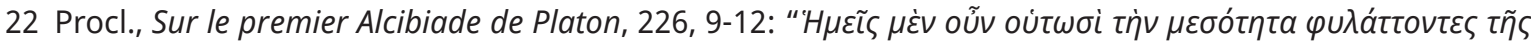
$\lambda$

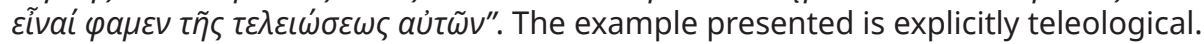


Proclus, nevertheless, will clarify that this is a qualitatively "measurable" process, which will unfold in unhurried ways. Thus, so to speak, metaphysical feeds will not divert the human consciousness either to an excessive or, of course, to an elliptical and subconscious initiative on its part ${ }^{23}$. The reference to the realistic measure is clear.

The later scholar of the Platonic Academy will emphasize that his above formulations would no longer give room for acceptance of the broader - on this issue - views of prosocratic philosophers. He points out, in fact, that the majority of these thinkers overlook the immaterial, spiritual and reasonably situated state of the human psyche and, consequently, of psychology. He notes that, in the event that he himself accepted or appropriated such a view, he would be tempted to "subdue" in the cosmological perspectives of Hereafter all the extra-temporal and supernatural elements of There. Thus, the ontological degradation of evaluative and at the same time hierarchical priorities in general would be inevitable and, of course, "boxed" in a way of metaphysical materialism ${ }^{24}$.

From another point of view, Proclus chooses to place in the field of his own enlarged problematic the corresponding approach of Plotinus, in which, remarkably, he foresees, interpretive difficulties similar to that of the Prosocratics. According to the historical leader of Neoplatonism, the human soul is placed in an entrenched and constant state of divinity even during its world tour - when it remains as ontologically autonomous from what is happening within the empirical world ${ }^{25}$. In what way is transcendental content acquired. However, according to the late Neoplatonic philosopher, such an interpretive view of the human interior would possibly mean that it would be in a permanent state of apathy, where the mental as well as the psychological components of human consciousness would not overlap in the end in any pre-eschatological way. This situation would probably concern a person who not only remained completely distanced from the physical and social events, but also in the field of his own organic processes would be at risk of suffering from any psychoneurotic diseases, as being under the regime of an individual-centered bipolarity, with spiritualism becoming absolute ${ }^{26}$. It would clearly be a human entity, which would exhibit a discontinuous, unedited and possibly irrelevant behavior in relation to its individual manifestations, which would be clearly inadmissible of any form of healing ${ }^{27}$.

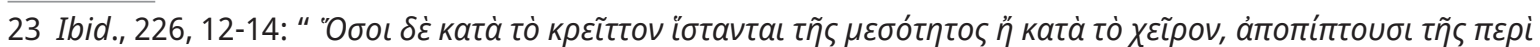

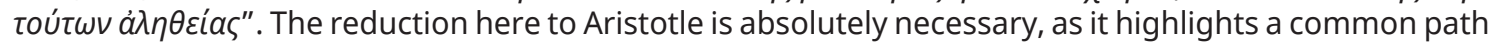
to mediocrity.

24 Ibid., 226, 14- 227, 3: “Oütc yà

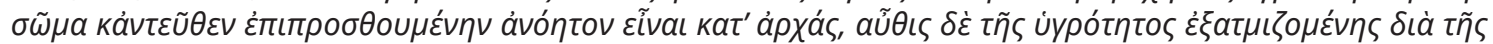

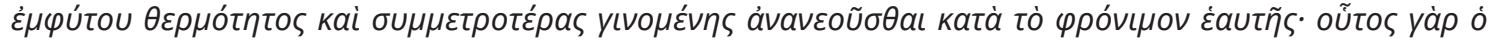

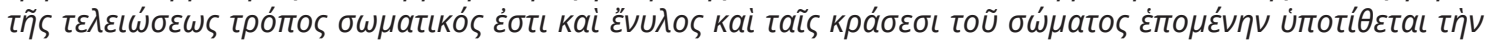

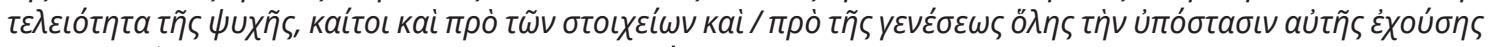

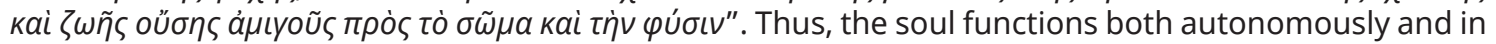
a relationship.

25 Cf. Watson 1928, 487-488.

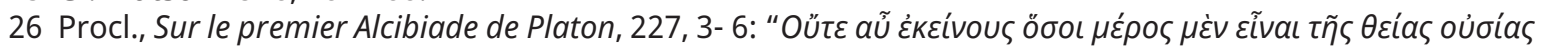

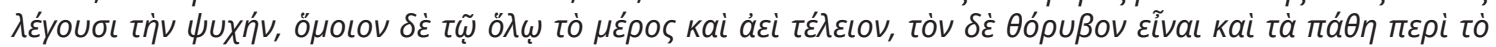

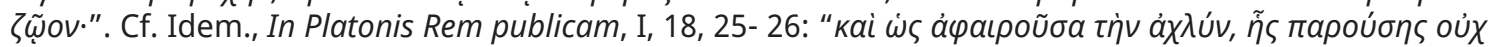

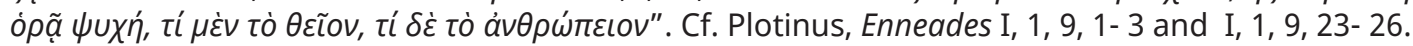

27 Procl., Sur le premier Alcibiade de Platon, 227, 6- 9: "oi yà

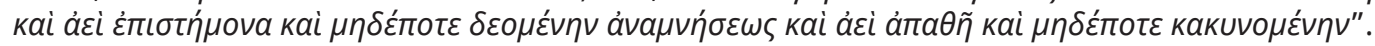


Therefore, we would argue that Proclus remains in this case a consistent admirer of the Platonic philosophical tradition, in which human consciousness participates - in the form of an active spiritual vision - of the "ideal" space, without, of course, existentially deviating from "vital mobility"28. What he is called to do is merely a dynamic reconstruction of the physical in terms of metaphysical teleology, so that, even in his worldly presence, he enjoys a state of philosophical bliss.

For Nemesius Emesis, respectively, human behavior is the voluntary result of an internal rational process of the individual, which causally depends on similar impulses ${ }^{29}$. However, the Christian thinker will then point out that any human act is not entirely certain to be based on an inner human predisposition, since it is possible to make correlations without relevant, preparatory to consciousness ${ }^{30}$. In the case, of course, in which the predisposition of an individual involves, according to the Byzantine thinker, rational contexts and, consequently, metaphysical origins or motives, the human consciousness will be activated by psychological necessity and, as such, will determine the corresponding psychic processes of a rational interiority ${ }^{31}$.

Depending on the Proclus, the Bishop of Emesis also insists on the indicative and on a case-by-case historical-philosophical examination of the subjects he introduces in the field of his theoretical discoveries. He also chooses to direct his references, albeit briefly, to the removal of the views of both the Prosocratics and Plotinus, to whom - among some other philosophers - he finds their attempt to systematically set absolute or vertical existential boundaries in area of the human interior. Thus, and accordingly to give to the psyche and psychology of human consciousness either an exclusively material or a one-dimensional divine orientation. In particular, as for the prosocratic philosophers, the Christian author will note that they, like the Stoics later, argue that the human interior involves mainly material connotations ${ }^{32}$. With regard to Plotinus, Nemesius will suffice to state only that for the Neoplatonic philosopher a human being consists of three parts -from the body, from the soul and from the mind-, clearly implying the theoid state of the soul, the which puts on the border of the materiality of the body and the divinity of the mental human element ${ }^{33}$.

Therefore, Nemesius could not accept positions and conjectures either, which either overemphasize the material element of the human interior or, on the other hand, bid for its divinity. In fact, he directly rejects the first version, mainly because it completely escapes the limitations introduced by the explicit Christian metaphysical realism ${ }^{34}$.

28 Lodge 1924, 34.

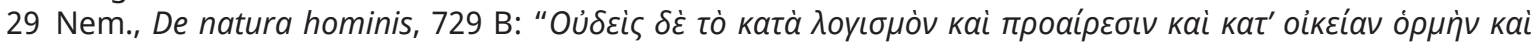

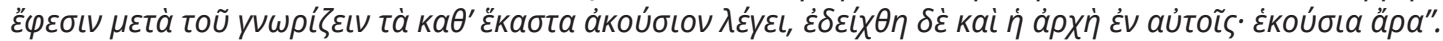

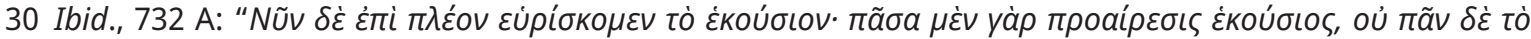

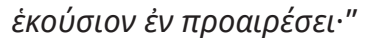

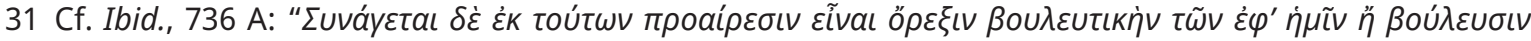

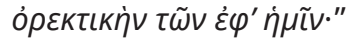

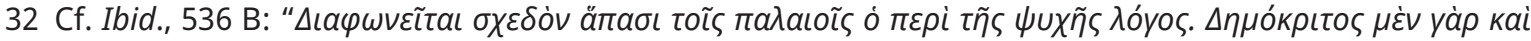

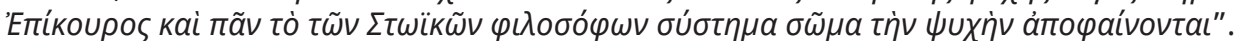

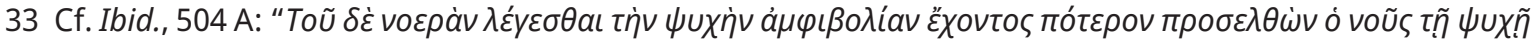

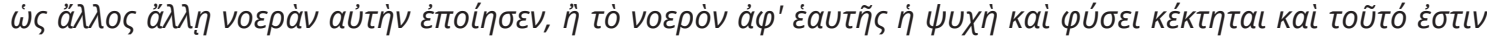

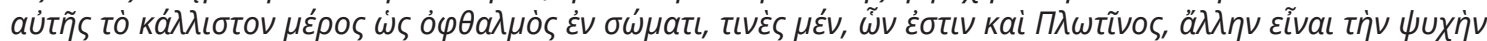

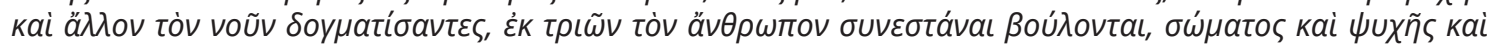
voũ". Cf. Watson 1928, 489.

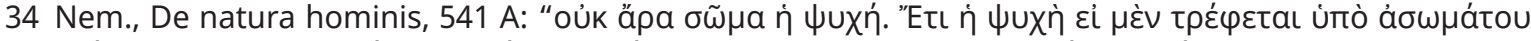

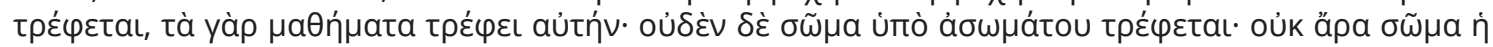
४uXń". 
As for the second case, then, the Byzantine thinker does not overlook, as has already been shown, the fact that the soul acts together with the body, with which, in fact, it develops an organic relationship, in a way, of reciprocity. From the broader context,

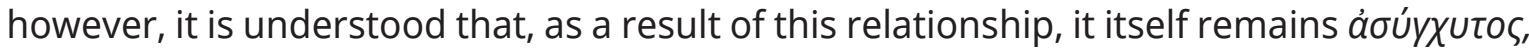

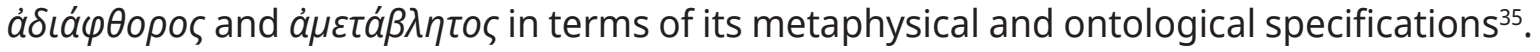
Therefore, we would note, with regard to the specific goal of this topic, that, both in its mental and in its psychological dimension, the human consciousness has in itself the qualitative conditions to achieve within the empirical space the transcendence of its constituents. as, however, an integral organic part of both its "macro" (nature) and its "micro" (body) appearance. As such, functional power, therefore, human consciousness will obviously not divert the individual from the natural and social consequences and, moreover, will not form personalities full of materialistic and psychoneurotic tendencies or pathogenesis.

It follows from the above that a human entity is defined on the one hand essentially - as a whole psychosomatic - on the other hand, but also substantially in terms of the way in which its conscious consciousness perceives as a mental event and interprets as psychological condition exactly this state ${ }^{36}$. Therefore, the human "conscious" emerges as a qualitatively "measurable quantity", as in both of the above versions it can be evaluated. After all, as M. Leone aptly points out, Christian Anthropology has accepted the influences of both Greek and Jewish thought on the idea of the human soul as a principle of individualization, which has the characteristics of variability - in the sense of immunity, agility, anticipation of the higher, but above all in the sense of "worrying slip" ${ }^{37}$. In the farthest, we recall again, its qualitative state, the human consciousness needs to seek its nourishment from its inherent spiritual connections with its divine primordial and, while attaining such levels of psychology, through the soul to rearrange its bodily functions accordingly, so as to redefine on the eschatologically most appropriate its relationship not only with the imaginary but also with the sensible world ${ }^{38}$.

In Proclus, as in Nemesius Emesis, the above culmination of the procedural performances of human consciousness arises as a result of its dynamic manifestations, the search for its metaphysical or even its eschatological "cure". Thus, from this point of view, she herself is not in a state of apathy, at least as far as the interior of a human being is concerned. A. Quinton, in fact, hastens to clarify that consciousness, either as a psychic or as a psychological event, is ultimately possible to reflect the experiential -dynamic- radiance of the human interior, even when it has not secured for herself albeit to a limited extent - familiar with her spiritual feedback ${ }^{39}$.

Just as the human consciousness can achieve, through the soul, its connection with its body - either in a positive or in a possibly negative perspective - this is exactly how it ensures the communication of the whole man with the physical and with the its social environment. It should be noted, however, that this development, in its qualitatively positive projection, involves a directly rational tool-eschatological for the individual- role,

35 Young 1983, 130.

36 Cf. Hatch 1898, 276.

37 Leone $2013,124$.

38 Cf. Clément 1973, 150.

39 Quinton 1962, 396. 
while in its negative version, despite the fact that it is even within the limits of ontological expulsion, is not deprived - at least indirectly - of the possibilities of a salvific "revival" 40 . In both cases, however, the human "conscious" needs to maintain a familiar relationship with its physical element, that is, with the body, as that is, according to M. Lipman and A. N. Whitehead, the field of reference in which rests "implicitly" not only the quantitative but, especially, the qualitative relations of the exogenous human, physical objects ${ }^{41}$.

Thus, man, neither according to Proclus nor, of course, according to Nemesius Emesis, needs to live isolated from the physically and socially occurring. And, under an eschatological view or interpretation, he needs to give them spiritual feedback and not to "erase" them consciously, so that either in his existential universality or as part of the material world he participates in divine Providence and divine Grace ${ }^{42}$. Thus, enlightenment and $\theta \varepsilon \circ \varphi$ áveıa will contribute not only to the clutches of the existential unity of man ${ }^{43}$, but also, even further, to the establishment of a metaphysical path, a relationship with his familiar environment. After all, the uncle permanently grants to the individual possibilities of salvific ascension, related to the embodied or the material "imprint" of his consciousness as a special whole achievement. ${ }^{44}$

Only then, in this way, is it possible for man to avoid falling into -unfortunately obviouslya state of mental or even psychological "neuroticism", where his material element will observe a dimensional attitude towards the spiritual or where his senses his world will be set as permanently inaccessible to his consciousness ${ }^{45}$. Of course, the removal of any of these vertical dividing lines will take its bridges through the activation of the spiritual forces of the human interior and not through the dominant influence of human external factors. ${ }^{46}$

\section{CONCLUSIONS-EXTENSIONS}

The neo-Platonist philosopher Proclus and the Christian thinker Nemesius Emesis, although starting from different worldviews, nevertheless "meet" in the field of their discoveries on key anthropological issues. The peculiar fact, which emerges from the so-called connection of Neoplatonism with Christianity, is that the field of Anthropology maintains some key autonomies, even if in its individual aspects it is articulated under the specific contextual conditions. Thus, in both the representatives of late Neoplatonism and those of Eastern Christianity, a human consciousness is defined as an existential event in the way in which it chooses to "identify" itself, that is, to "render" in a familiar way the, creeping into the whole of the existing, relationship of the Hereafter with the There.

40 Vidal 2002, 935-943.

41 Lipman 1957, 429. Cf. Whitehead 1929, 258. Cf. Trouillard 1982, 251-252.

42 Cf. Lossky 1974, 56.

43 Matsoukas 2000, 219.

44 Cobb 1987, 221.

45 Case 1923, 247.

46 Ibid., 247. Cf. Lossky 1973, 117. 
The undertaking of initiatives for this purpose clearly indicates that in both theoretical systems Anthropology clearly emerges as the philosophy or the theology of the "person", but also that in its paths it will use Metaphysics, Cosmology, Gnosticism but also Eschatology from the point of view alone with every way of reading the spatio-temporal apocalyptic projections of the Creator. Therefore, the dynamics of each "personal" consciousness is the one that can "trigger" the epiphanies within the existing, and therefore at the same time highlight the "how" and the "why" of its worldly presence, that is, to become an accomplice. God's.

\section{BIBLIOGRAPHY}

Barnes H. E. (1945): Neo-Platonism and Analytical Psychology, The Philosophical Review, 54/6, 558-577.

Bastid P. (1969): PROCLUS- Et le Crépuscule de la Pensée Grecque, "J. Vrin”, Paris.

Case S. J. (1923): The Art of Healing in Early Christian Times, The Journal of Religion, 3/3, 238-255.

Charles A. (1971): L'Imagination, miroir de l' âme chez Proclus, Le Neoplatonisme, Paris, 241-249.

Clément O. (1973): Theology after the "death of God", ed. by Ch. Giannaras, "Athena", Athens.

Cobb J. B. (1987): The Resurrection of the Soul, The Harvard Theological Review, 80/2, 213-227.

Gerson L. P. (1986): Platonic Dualism, The Monist, 69/3, 352-369.

Goeschel K. F. - Vickroy T. R. (1877): Dogmatic Proofs of the Immortality of the Human Soul, The Journal of Speculative Philosophy, 11/2, 177-197.

Hann C. (2014): The Heart of the Matter Christianity, Materiality and Modernity, Current Anthropology, 55/10, 182-192.

Hatch E. (1898): The Influence of Greek Ideas and Usages upon the Christian Church, "Williams and Norgate", Oxford.

Leone M. (2013): Signs of the Soul: Toward a Semiotics of Religious Subjectivity, Signs and Society, 1/1, 115-159.

Lipman M. (1957): The Aesthetic Presence of the Body, The Journal of Aesthetics and Art Criticism, 15/4, 425-434.

Lodge R. C. (1924): Soul, Body, Wealth in Plato (II), The Philosophical Review, 33/1, 30-50.

Lossky V. (1974): In the image and likeness of God, Greek trans. by M. G. Michailidis, “B. Rigopoulou", Thessaloniki.

Lossky V. (1973): The view of God, Greek trans. by M. Kalamaras, “B. Rigopoulou”, Thessaloniki.

Matsoukas N. A. (2000): Dogmatic and Symbolic Theology A'-Introduction to theological epistemology, "P. Pournara ", Thessaloniki.

Quinton A. (1962): The Soul, The Journal of Philosophy, 59/15, 393-409.

Sheppard A., Proclus attitude to Theurgy, Classical Quarterly, 32, 212- 224.

Terezis C. A. (1991): The apophatic theology and the cognitive forces of the soul according to Proclus, Hellenic Philosophical Review, 8, 300-314.

Trouillard J. (1982): La Mystagogie de Proclos, "Les Belles Lettres", Paris.

Trouillard J. (1971): L'Antithèse Fondamentale de la Procession selon Proclos, Archives de Philosophie, 34, 433-499. 
Vidal F. (2002): Brains, Body, Selves and Science: Anthropologies of Identity and the Resurrection of the Body, Critical Inquiry, 28/ 4, 930-974.

Watson J. (1928): The Philosophy of Plotinus, The Philosophical Review, 37/5, 482-500.

Whitehead A. (1929): N., Process and Reality, "Macmillan Company", New York.

Whiton-Calkins M. (1908): Self and Soul, The Philosophical Review, 17/3, 272-280.

Young F.M. (1983): Adam and Anthropos: A Study of the Interaction of Science and the Bible in Two Anthropological Treatises of the Fourth Century, Vigiliae Christianae, 37/2, 110-140. 


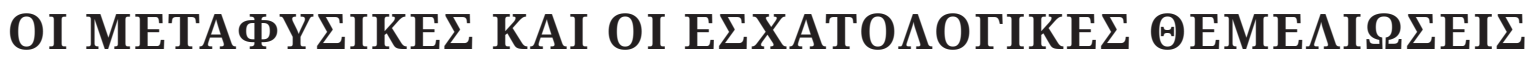

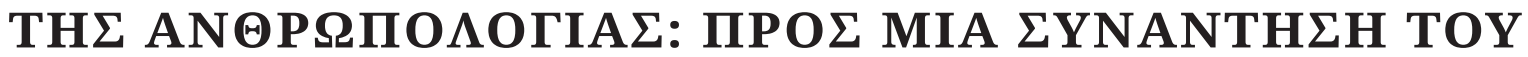

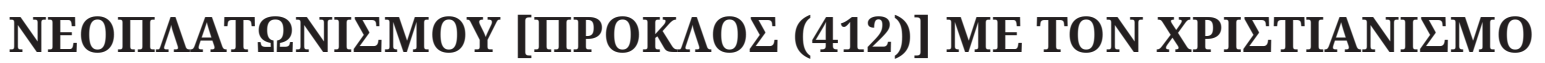 [NEME $\Sigma I O \Sigma$ EME $\Sigma H \Sigma(400)]$}

\section{Summary:}

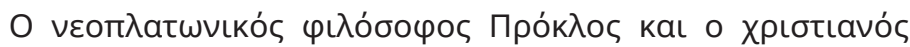

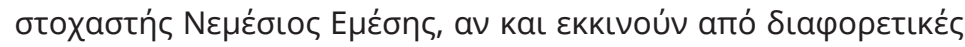

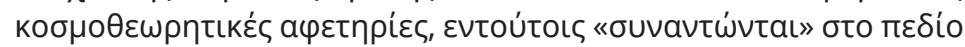

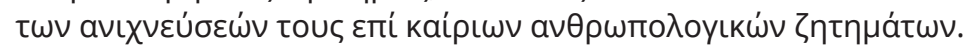

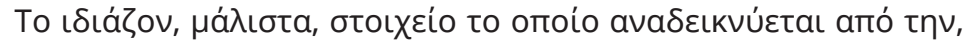

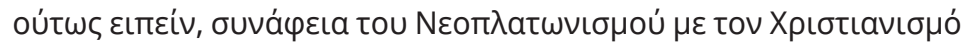

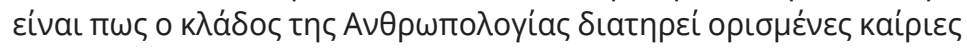

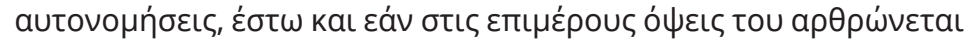

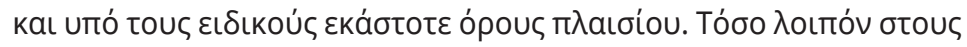

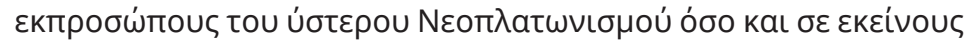

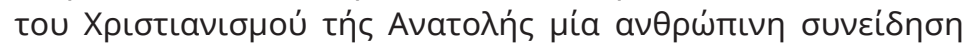

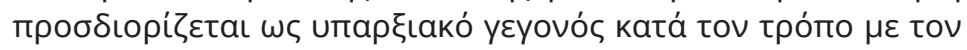

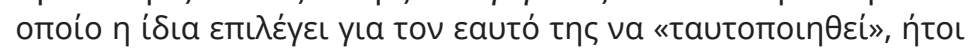

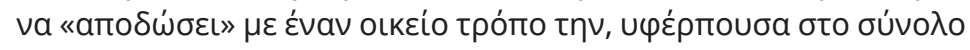

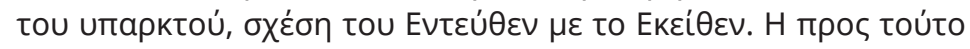

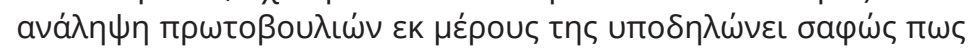

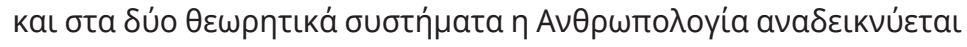

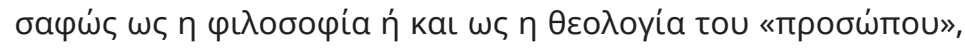

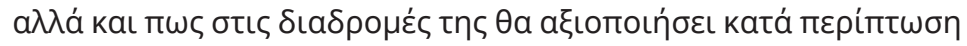

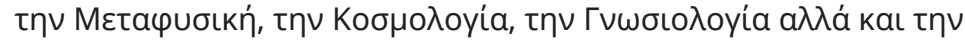

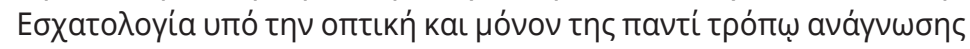

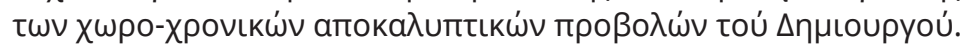

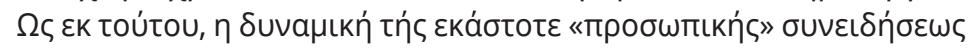

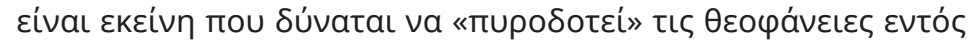

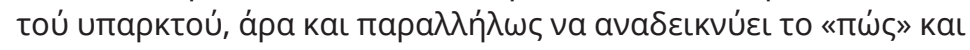

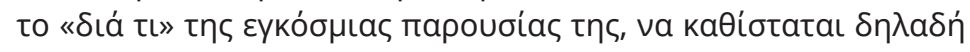

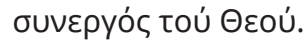

\section{Keywords:}

Про́к入о५,

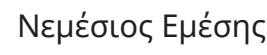

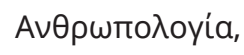

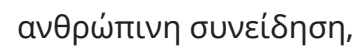

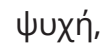

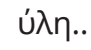

